Available online at GSC Online Press Directory

GSC Biological and Pharmaceutical Sciences

e-ISSN: 2581-3250, CODEN (USA): GBPSC2

Journal homepage: https://www.gsconlinepress.com/journals/gscbps

(RESEARCH ARTICLE)

\title{
Effects of salinity stress on the growth performance of two varieties of Kenaf (Hibiscus cannabinus L.)
}

\author{
Ehoniyotan Olayemi Ibukun *, Sani Daniel Eneji and Abejide Dorcas Ropo \\ Department of Plant Science and Biotechnology, Kogi State University, Anyigba, Kogi State, Nigeria.
}

Publication history: Received on 09 April 2020; revised on 13 April 2020; accepted on 15 April 2020

Article DOI: https://doi.org/10.30574/gscbps.2020.11.1.0093

\begin{abstract}
Salinity stress is one of the most serious factors limiting the productivity of agricultural crops with adverse effects on germination, plant vigor and crop yield. This experiment was conducted to determine the effects of salinity stress on HIB 16 and HIB 17 varieties of Kenaf (Hibiscus cannabinus) grown in pots under greenhouse conditions. Salinity treatments of $4 \mathrm{ds} / \mathrm{m}, 6 \mathrm{ds} / \mathrm{m}$ and $8 \mathrm{ds} / \mathrm{m}$ were applied for a period of 9 weeks and the physiological changes in the plants were observed. Results revealed that there was no significant difference between the $4 \mathrm{ds} / \mathrm{m}$ treatment and control of HIB 16 variety in terms of leaf numbers, stem heights, fresh weights and dry weights throughout the weeks of observation but with an increase in concentration to $6 \mathrm{ds} / \mathrm{m}$ and $8 \mathrm{ds} / \mathrm{m}$ significant decrease were observed in leaf numbers, stem heights, fresh weights and dry weights. At 4 weeks of $8 \mathrm{ds} / \mathrm{m}$ treatment the leaves were all withered on HIB 17 variety but there were still leaves on HIB 16 until after the 6th week. The highest recorded height was $65 \mathrm{~cm}$ and the highest leaf number was 26.67 in control of HIB 16 variety. This work has revealed that kenaf can be grown successfully in moderate saline water. However salt levels of $4 \mathrm{ds} / \mathrm{m}$ and above can restrict plant growth and development resulting to significant yield reduction.
\end{abstract}

Keywords: Kenaf; Salinity; Varieties; Treatments; Significant

\section{Introduction}

Kenaf (Hibiscus cannabinus L.) is a short day, yearly herbaceous fiber crop belonging to the family Malvaceae [1]. The Malvaceae family is noted for their economic and horticultural importance. Kenaf is one of the most important fiber crops in the world [2]. Kenaf plant probably originated from sub-Saharan Africa with evidence of its domestication around $4000 \mathrm{BC}$ in the Sudan region [3].

Salinization is a process that results in an increased concentration of salts in soil and water. Of these salts, sodium chloride is the most common [4]. Salinity is one of the most serious factors limiting the productivity of agricultural crops, with adverse effects on germination, plant vigor and crop yield [5]. Salinization affects many irrigated areas mainly due to the use of brackish water. Worldwide, more than 45 million hectares of irrigated land have been damaged by salt, and 1.5 million hectares are taken out of production each year as a result of high salinity levels in the soil [5].

High salinity affects plants in several ways: water stress, ion toxicity, nutritional disorders, oxidative stress, alteration of metabolic processes, membrane disorganization, reduction of cell division and expansion, and genotoxicity among others. Together, these effects reduce plant growth, development and survival $[6,7]$.

The mechanisms of genetic control of salt tolerance in plants have not yet been fully understood because of its complexity. There are in fact several genes controlling salinity tolerance in the different species whose effect interacts strongly with environmental conditions. Thus, genetic variation can only be demonstrated indirectly, by measuring the

\footnotetext{
${ }^{*}$ Corresponding author: Ehoniyotan Olayemi Ibukun
}

Copyright (C) 2020 Author(s) retain the copyright of this article. This article is published under the terms of the Creative Commons Attribution Liscense 4.0. 
responses of different genotypes. Probably the most suitable response to measure is growth or yield, especially at moderate salinities [8].

The sensitivity to salinity of a given species may change during ontogeny. Salinity tolerances may increase or decrease depending on the plant species and/or environmental factors. For some species, salt sensitivity may be greatest at germination, whereas for other species, sensitivity may increase during reproduction [9].

Soil salinity is a major abiotic constraint affecting yield. This has necessitated many research works in developing crops tolerant to salinity stress. However, since there is a wide range of salt tolerance in vascular plants, with majority being glycophytes, this research work will provide information on the tolerance level to salinity stress on the growth of two varieties of Kenaf (Hibiscus cannabinus)..

\section{Material and methods}

\subsection{Apparatus and materials}

The apparatus used during the course of this research work were beakers, glass funnels, measuring cylinder, stirrers, conical flasks, masking tape, electronic weighing machine, EC meter (Syntronics), polythene bags and garden trowel.

\subsection{Salt sample}

Pure Samples of Sodium Chloride used in this study was produced by Merck Co., Germany.

\subsection{Soil}

Top sandy loam soil from non-saline A horizon of organic soil was collected from University Village, Kogi State University. Soil was air dried for $72 \mathrm{hrs}$, cleaned for stones and straws. The leather bags were filled with thee soil sample.

\subsection{Seeds}

Two varieties of Kenaf (Hibiscus cannabinus); HIB 16 and HIB17 used in this experiment were obtained from National Center for Genetic Resources and Biotechnology (NACGRAB), Ibadan.

\subsection{Preparation of $\mathrm{NaCl}$ solution}

Three salt solutions were prepared using AR grade Sodium Chloride (M.W- 58.44) by the given relationship: (TDS (g/l) $=0.6 \times \mathrm{EC}(\mathrm{dS} / \mathrm{m}))$ for EC 4,6 and $8 \mathrm{ds} / \mathrm{m}$ to irrigate the plants for the given period of the salt stress for evaluation of salinity tolerance. Salt solutions were prepared for $1000 \mathrm{ml}$ and desired amount of $\mathrm{NaCl}$ was added in Distilled Water. The Electrical Conductivity (EC) was measured using EC meter (Syntronics) as described by Rani and Sharma [10].

For $\mathrm{EC}=4 \mathrm{ds} / \mathrm{m}, 2 \mathrm{gm} \mathrm{NaCl}$ was added to $1000 \mathrm{ml}$ distilled water.

For $\mathrm{EC}=6 \mathrm{ds} / \mathrm{m}, 3 \mathrm{gm} \mathrm{NaCl}$ was added to $1000 \mathrm{ml}$ distilled water.

For $\mathrm{EC}=8 \mathrm{ds} / \mathrm{m}, 4 \mathrm{gm} \mathrm{NaCl}$ was added to $1000 \mathrm{ml}$ distilled water.

\subsection{Experiment site}

The research work was carried out in a secured location within Kogi State University Village, Anyigba (Latitude $7^{0} 6^{1} \mathrm{~N}$ and Longitiude $7^{0} 43^{1}$ ), Kogi State Nigeria. Anyigba is located in the southern agro-ecological zone of Nigeria.

\subsection{Experimental design}

The layout of the experiment was a Random block design, with three replicates. 6 seeds were used for each treatment in every replicate; the total number of seeds used in the experiment was 156 seeds.

\subsection{Data collection}

\subsubsection{Shoot height}

Height of the plant was measured in centimeters from ground level to the shoot tip point, with the help of measuring tape/meter. 


\subsubsection{Leaf number}

This was determined by counting the number of leaves.

\subsubsection{Fresh weight}

The soil on the harvested plant parts were washed with tap water and were spread on filter paper for drying. The fresh weight of the whole plant was determined using electronic weighing machine.

\subsubsection{Dry weight}

After taking the fresh weights, the plants were spread in an empty room to dry before the dry weight of the whole plant was determined using electron weighing machine.

\subsection{Statistical analysis}

The data collected were analyzed using Analysis of Variance (ANOVA) $\backslash$ and SPSS 20 Version. Means were compared using Duncan Multiple Range Test. Values were expressed as Mean \pm S. D. The level of significance was taken at $\mathrm{P}<0.05$.

\section{Results and discussion}

Table 1 Effect of salinity stress on the leaf numbers of two varieties of Kenaf

\begin{tabular}{llllll}
\hline Variety & Treatment & 2weeks & 4weeks & 6weeks & 9weeks \\
\hline (HIB 16) & Control & $5.33 \pm 0.58$ & $17.33 \pm 0.58^{\mathrm{a}}$ & $23.00 \pm 1.00^{\mathrm{a}}$ & $26.67 \pm 0.58^{\mathrm{a}}$ \\
& $4 \mathrm{ds} / \mathrm{m}$ & $5.33 \pm 0.58$ & $17.33 \pm 1.53^{\mathrm{a}}$ & $21.00 \pm 1.00^{\mathrm{a}}$ & $25.00 \pm 1.00^{\mathrm{a}}$ \\
& $6 \mathrm{ds} / \mathrm{m}$ & $4.67 \pm 0.58$ & $12.33 \pm 1.53^{\mathrm{bc}}$ & $9.00 \pm 7.81^{\mathrm{bc}}$ & $4.67 \pm 8.08^{\mathrm{bc}}$ \\
& $8 \mathrm{ds} / \mathrm{m}$ & $4.00 \pm 1.00 \mathrm{NS}$ & $5.67 \pm 1.15^{\mathrm{d}}$ & $2.67 \pm 4.62^{\mathrm{cd}}$ & $0.00 \pm 0.00^{\mathrm{c}}$ \\
(HIB17) & Control & $4.67 \pm 0.58$ & $15.33 \pm 1.53^{\mathrm{a}}$ & $19.67 \pm 1.53^{\mathrm{a}}$ & $23.33 \pm 1.53^{\mathrm{a}}$ \\
& $4 \mathrm{ds} / \mathrm{m}$ & $4.00 \pm 0.58$ & $12.67 \pm 1.53^{\mathrm{b}}$ & $16.33 \pm 0.58^{\mathrm{ab}}$ & $11.00 \pm 9.53^{\mathrm{b}}$ \\
& $6 \mathrm{ds} / \mathrm{m}$ & $4.33 \pm 0.58$ & $10.33 \pm 1.55^{\mathrm{c}}$ & $8.67 \pm 7.57^{\mathrm{bc}}$ & $4.67 \pm 8.08^{\mathrm{bc}}$ \\
& $8 \mathrm{ds} / \mathrm{m}$ & $4.00 \pm 1.00 \mathrm{NS}$ & $0.00 \pm 00.00^{\mathrm{e}}$ & $0.00 \pm 0.00^{\mathrm{d}}$ & $0.00 \pm 0.00^{\mathrm{c}}$ \\
\hline \multicolumn{5}{c}{ Values are means \pm standard deviation, values followed by different alphabet(s) in a column } \\
are significantly different at P<0.05 tested by Duncan Multiple Range Test.
\end{tabular}

Results presented in Table 1 shows that at higher levels of salinity ( $6 \mathrm{ds} / \mathrm{m}$ and $8 \mathrm{ds} / \mathrm{m}$ ) from the fourth week of exposure led to significant decrease of leaf number in the two varieties of kenaf. It was found that the general trend of the treatment reflects a gradual decrease in the number of plant leaves with the increase of salt concentration, compared with the plants of the control experiment, except for the $4 \mathrm{ds} / \mathrm{m}$ treatment, which showed no significant decrease of leaves throughout the experiment in the HIB16 variety, whereas the same concentration led to a significant decrease in the number of leaves in the HIB 17 variety. At 4wks, there was total loss of leaves of HIB 17 variety treated with $8 \mathrm{ds} / \mathrm{m}$. These results are quite similar with the results of [11] on Chickpeas (Cicer arietinum L.) and [12] on Tepary bean (Phaseolus acutifolius L.), cowpea (Vigna unguiculata L.), and wild bean (Phaseolus filiformis L) who reported that the treatment of sodium chloride reduced the number of leaves compared with control plants. [13] reported that the treatment of Cabbage (Brassica oleracea capitata L. and Brassica oleracea botrytis L.) with the concentrations: 0, 4.7, $9.4,14.1 \mathrm{ds} / \mathrm{m}$ of $\mathrm{NaCl}$, had a negative effect on leaf number of these plants.

Gama et al. [14] also reported that there is a decrease in the number of leaves of beans (Phaseolus vulgaris L.) when treated with 50 , and $100 \mathrm{mM}$ of sodium chloride.

The decrease of leaf numbers may be due to the accumulation of sodium chloride in the cell walls and cytoplasm of the older leaves. At the same time, their vacuole sap cannot accumulate more salt and, thereby decreases the concentration of salt inside the cells, which ultimately leads to their quick death and cut down [6]. 
Ehoniyotan et al. / GSC Biological and Pharmaceutical Sciences, 2020, 11(01), 121-126

Table 2 Effect of salinity stress on the shoot heights of two varieties of Kenaf

\begin{tabular}{llllll}
\hline Variety & Treatment & $\begin{array}{l}\text { 2weeks } \\
\text { (cm) }\end{array}$ & $\begin{array}{l}\text { 4weeks } \\
\text { (cm) }\end{array}$ & $\begin{array}{l}\text { 6weeks } \\
\text { (cm) }\end{array}$ & $\begin{array}{l}\text { 9weeks } \\
\text { (cm) }\end{array}$ \\
\hline (HIB16) & Control & $1600 \pm 1.00^{\mathrm{a}}$ & $26.03 \pm 1.05^{\mathrm{a}}$ & $43.83 \pm 0.76^{\mathrm{a}}$ & $65.17 \pm 1.04^{\mathrm{a}}$ \\
& $4 \mathrm{ds} / \mathrm{m}$ & $15.67 \pm 0.58^{\mathrm{a}}$ & $25.97 \pm 0.72^{\mathrm{a}}$ & $43.17 \pm 0.76^{\mathrm{a}}$ & $62.33 \pm 2.52^{\mathrm{a}}$ \\
& $6 \mathrm{ds} / \mathrm{m}$ & $13.33 \pm 1.53^{\mathrm{b}}$ & $15.83 \pm 1.26^{\mathrm{c}}$ & $09.50 \pm 8.23^{\mathrm{c}}$ & $5.23 \pm 9.06^{\mathrm{bc}}$ \\
& $8 \mathrm{ds} / \mathrm{m}$ & $10.67 \pm 1.53^{\mathrm{c}}$ & $13.67 \pm 2.31^{\mathrm{d}}$ & $4.17 \pm 7.22^{\mathrm{cd}}$ & $0.00 \pm 0.00^{\mathrm{c}}$ \\
(HIB17) & Control & $12.67 \pm 0.58^{\mathrm{a}}$ & $22.33 \pm 1.15^{\mathrm{b}}$ & $38.67 \pm 2.08^{\mathrm{a}}$ & $56.00 \pm 3.61^{\mathrm{a}}$ \\
& $4 \mathrm{ds} / \mathrm{m}$ & $12.67 \pm 1.15^{\mathrm{a}}$ & $17.83 \pm 0.76^{\mathrm{c}}$ & $18.50 \pm 0.62^{\mathrm{b}}$ & $12.15 \pm 10.52^{\mathrm{b}}$ \\
& $6 \mathrm{ds} / \mathrm{m}$ & $9.33 \pm 1.15^{\mathrm{b}}$ & $12.23 \pm 0.68^{\mathrm{d}}$ & $9.00 \pm 7.81 \mathrm{c}$ & $4.80 \pm 8.31^{\mathrm{bc}}$ \\
& $8 \mathrm{ds} / \mathrm{m}$ & $9.33 \pm 0.58^{\mathrm{b}}$ & $0.00 \pm 0.00^{\mathrm{e}}$ & $0.00 \pm 0.00^{\mathrm{d}}$ & $0.00 \pm 0.00^{\mathrm{c}}$ \\
\hline
\end{tabular}

Values are means \pm standard deviation, values followed by different alphabet(s) in a column are significantly different at $\mathrm{P}<0.05$ tested by Duncan Multiple Range Test.

The heights of the plants under salt stress during the treatment periods presented in Table 2 indicates that heights of HIB 16 variety exposed to $4 \mathrm{ds} / \mathrm{m}$ had no significant difference from the control plants throughout the weeks of observation, while heights of those exposed to higher salinity concentrations ( $6 \mathrm{ds} / \mathrm{m}$ and $8 \mathrm{ds} / \mathrm{m})$ expressed an inverse relationship. HIB 17 showed significant decrease in heights between control plants and $4 \mathrm{ds} / \mathrm{m}$ plants at 4 weeks, 6 weeks, 8 weeks and 9 weeks. Increase in concentration of salinity led to further significant decrease in shoot heights. The result follows the trend of earlier published results of [15] on cowpea (Vigna unguiculata L.) and [16] on Field Mustard (Brassica campestris) that the use of low concentrations of sodium chloride had little or no effects on plants height, whereas higher concentrations caused shortage. Similar results of increase in salinity stress leading reduced plant heights have also been reported by [17] on Moth bean (Vigna aconitifolia L.), [13] on Radish plant (Raphanus Sativus L.) and [18] on Black gram (Vigna mungo L.). The noticed decrease in the length of the stem due to treatment with sodium chloride solution could be due to the negative effect of this salt on the rate of photosynthesis, and also the decrease in the level of carbohydrates and growth hormones, both of which can lead to inhibition of the growth [19].

Table 3 Effect of salinity stress on the fresh and dry weights of two varieties of Kenaf

\begin{tabular}{llll}
\hline & Treatment (ds/m) & Fresh weight 2WAT & Dry weight 2WAT \\
\hline (HIB 16) & Control & $2.52 \pm 0.02^{\mathrm{a}}$ & $0.58 \pm 0.03^{\mathrm{a}}$ \\
& $4 \mathrm{ds} / \mathrm{m}$ & $2.51 \pm 0.02^{\mathrm{a}}$ & $0.56 \pm 0.05^{\mathrm{a}}$ \\
& $6 \mathrm{ds} / \mathrm{m}$ & $2.39 \pm 0.03^{\mathrm{a}}$ & $0.56 \pm 0.05^{\mathrm{a}}$ \\
& $8 \mathrm{ds} / \mathrm{m}$ & $2.07 \pm 0.20^{\mathrm{b}}$ & $0.26 \pm 0.04^{\mathrm{d}}$ \\
(HIB 17) & Control & $2.63 \pm 0.23^{\mathrm{a}}$ & $0.55 \pm 0.03^{\mathrm{a}}$ \\
& $4 \mathrm{ds} / \mathrm{m}$ & $2.44 \pm 0.04^{\mathrm{a}}$ & $0.48 \pm 0.01^{\mathrm{b}}$ \\
& $6 \mathrm{ds} / \mathrm{m}$ & $2.06 \pm 0.31^{\mathrm{b}}$ & $0.40 \pm 0.04^{\mathrm{c}}$ \\
& $8 \mathrm{ds} / \mathrm{m}$ & $1.73 \pm 0.08^{\mathrm{c}}$ & $0.31 \pm 0.04^{\mathrm{d}}$ \\
\hline
\end{tabular}

Values are means \pm standard deviation, values followed by different alphabet(s) in a column are significantly different at $\mathrm{P}<0.05$ tested by Duncan Multiple Range Test. *WAT: Week after treatment

Results presented in Tables 3 indicate that there is a slightly negative effect of salt stress on the fresh and dry weight of the two varieties kenaf. Comparing the recorded fresh weights of the different treatments with the values of control plants, there were significant differences in plants of $8 \mathrm{ds} / \mathrm{m}$ of HIB 16 and plants of $6 \mathrm{ds} / \mathrm{m}$ and $8 \mathrm{ds} / \mathrm{m}$ of HIB 17 with the other treatments and control of both varieties. There were also significant differences in dry weights. Many studies have shown either negative or positive effects of changes in salinity concentration, type of salt present, or type of plant species on fresh and dry weights of the shoot system $(20,21,22,23,16)$. 
The result of this work indicates a negative effect of salt stress on fresh and dry weights of two Kenaf varieties at two weeks. This is supported by [24] on radish plants (Raphanus sativus L.), [25] on Yellow oleander (Kyllinigia peruviana L.) and [16] on Field mustard (Brassica campestris L.) who all reported negative effects with increased salinity treatment. Contrary to this result, [15] on cowpea (Vigna unguiculata L.) and many other studies have reported the positive effect of sodium chloride on fresh and dry weights.

\section{Conclusion}

Kenaf can be grown successfully with moderately saline irrigation water. However, salt levels in excess of $4 \mathrm{ds} / \mathrm{m}$ in the irrigation water will severely restrict plant growth and development and will result in a significant yield reduction. HIB 17 variety showed more negative effect of salt treatments compared to HIB 16 which tend to be more tolerant.

\section{Compliance with ethical standards}

\section{Acknowledgments}

Special thanks to National Center for Genetic Resources and Biotechnology (NACGRAB), Ibadan who provided the Kenaf seeds used for this work.

\section{Disclosure of conflict of interest}

There is no conflict of interest.

\section{References}

[1] H'ng PS, Khor BN, Tadashi N, Aini ASN and Paridah MT. (2009). Anatomical structure and morphology of new kenaf varieties. Asian Journal of Scientific Research, 2(3), 161-166.

[2] Akinrotimi CA and Okocha PI. (2018). Evaluation of genetic divergence in kenaf (H. cannabinus L.) genotypes using agro-morphological characteristics. Journal of Plant Sciences and Agricultural Research, 2(12), 1-10.

[3] Cheng Z, Bao K, Sameshima DXF and Chen JK. (2004). Identification and genetic relationship of Kenaf germplasm revealed by AFLP analysis. Genetic Resource Crop Evolution, 51, 393-401.

[4] Chinnusamy V, A Jagendorf and JK Zhu. (2005). Understanding and improving salt tolerance in plants. Journal of Crop Science, 45, 437-448.

[5] Munns R and Tester M. (2008). Mechanisms of salinity tolerance. Annual. Review of Plant Biology, 59, $651-681$.

[6] Munns R. (2002). Comparative physiology of salt and water stress. Plant Cell and Environment. 25, 239-250.

[7] Zhu JK. (2007). Plant Salt Stress. John Wiley \& Sons, Ltd., Hoboken, NJ.

[8] Allen JA, Chambers JL and Stine M. (1994a). Prospects for increasing the salt tolerance of forest trees: A review. Tree Physiology, 14, 843-853.

[9] Howat D. (2000). Acceptable Salinity, Sodicity and pH Values for Boreal Forest Reclamation. Available at www.gov.ab.ca/env/protenf/landrec/index.html. In E. S. D. Alberta Environment, Edmonton Alberta. Report \# ESD/LM/00-2. 191.

[10] Rani B and Sharma VK. (2015). Standardization of methodology for obtaining the salt stress environment for salinity effect observation in rice seedlings. International Journal of Environmental Sciences, 6(2), 232-236.

[11] Karen W, Anthony RY and Timothy JF. (2002). Effects of salinity and ozone, individually and in combination on growth and ion contents of two chickpeas (Cicer arietinum L.) varieties. Environmental Pollution, 120(2), 397403.

[12] Raul L, Andres O, Armado L, Bernardo M and Enrique T. (2003). Response to salinity of three grain legumes for potential cultivation in arid areas (plant nutrition). Journal of Soil Science and Plant Nutrition, 49(3), 329-336.

[13] Jamil M, Rehman S and Rha ES. (2007). Salinity effect on plant growth, ps11 photochemistry and chlorophyll content in sugar beet (Beta vulgaris L.) and cabbage (Brassica oleracea capitata L.). Pakistan Journal of Botany, 39 (3), 753-760. 
[14] Gama PBS, Inanaga S, Tanaka K and Nakazawa R. (2007). Physiological response of common bean (Phaseolus vulgaris L.) seedlings to salinity stress. African Journal of Biotechnology, 6 (2), 79-88.

[15] Dantus BF, Ribeiro L and Aragao CA. (2005). Physiological response of cowpea seeds to salinity stress. Revista Brasileria de. Sementes, 27(1), 144-148.

[16] Memon SA, Hou X and Wang LJ. (2010). Morphological analysis of salt stress response of pak Choi. Electronic Journal of Environmental, Agricultural and Food Chemistry, 9(1), 248-254.

[17] Mathur N, Singh J, Bohra S, Bohra A and Vyas A. (2006). Biomass production, productivity and physiological changes in moth bean genotypes at different salinity levels. American Journal of Plant Physiology, 1(2), $210-213$.

[18] Taffouo VD, Wamba OF, Yombi E, Nono GV and Akoe A. (2010). Growth, yield, water status and ionic distribution response of three bambara groundnut (Vigna subterranean (L.) verdc.) landraces grown under saline conditions. International Journal of Botany, 6(1), 53-58.

[19] Mazher AMA, El-Quesni EMF and Farahat MM. (2007). Responses of ornamental and woody trees to salinity. World Journal of Agricultural Sciences, 3(3), 386-395.

[20] Jamil M, Lee CC, Rehman SU, Lee DB, Ashraf M and Rha ES. (2005). Salinity(NaCl) tolerance of brassica species at germination and early seedling growth. Electronic Journal of Environmental, Agricultural and Food Chemistry, ISSN, 1579-4377.

[21] Niaz BH, Athar M, Salim M and Rozema J. (2005). Growth and ionic relations of fodder beet and sea beet under saline. CEERS, 2(2), 113-120.

[22] Saffan SE. (2008). Effect of salinity and osmotic stresses on some economic plants. Research Journal of Agriculture and Biological Sciences, 4(2), 159-166.

[23] Rui L, Wei S, Mu-xiang C, Cheng-jun J, Min W and Bo-ping Y. (2009). Leaf anatomical changes of Burguiera gymnorrhiza seedlings under salt stress. Journal of Tropical and Subtropical Botany, 17(2), 169-175.

[24] Jamil M, Rehman SU, Lee KJ, Kim JM and Rha HK. (2007b). Salinity reduced growth ps2 photochemistry and chlorophyll content in radish. Scientia Agricola (Piracicaba, Braz.), 64(2), 111-118.

[25] Ha E, Ikhajiagba B, Bamidele JF and Ogic-odia E. (2008). Salinity effects on young healthy seedling of Kyllingia peruviana collected from escravos, Delta state. Global Journal of Environmental Research, 2(2), 74-88.

\section{How to cite this article}

Ehoniyotan OI, Sani DE and Abejide DR. (2020). Effects of salinity stress on the growth performance of two varieties of Kenaf (Hibiscus cannabinus L.). GSC Biological and Pharmaceutical Sciences, 11(1), 121-126 